\title{
RANCANG BANGUN APLIKASI HYBRID PENGOLAHAN DATA ANGGOTA DAN EVENT PADA CABANG OLAHRAGA (CABOR) TAEKWONDO KOTA MATARAM
}

\author{
(Designing Hybrid Applications for Processing Data Members and Events at the \\ Taekwondo Sports Branch in Mataram City
}

\author{
Baiq Azizah Tauhida, Royana Afwani ${ }^{*}$, Sri Endang Anjarwani \\ Dept Informatics Engineering, Mataram University \\ Jl. Majapahit 62, Mataram, Lombok NTB, INDONESIA \\ Email: ezawardana6@gmail.com, royana@unram.ac.id, endang@unram.ac.id
}

\begin{abstract}
Abstrak
Taekwondo is one of the most popular martial arts in the world. Based on the data obtained, in the Province of West Nusa Tenggara (NTB) there were 59 training sites, also called Dojang, and the biggest ones were in the City of Mataram. There are so many tournament and event at Taekwondo sport. In participating in these event, member data and other requirements are always checked. The checking process is still manual so it tends to be complicated and vulnerable to manipulation. In this study, a hybrid application of member data processing and event was designed and made on mobilebased Mataram City Taekwondo sports, as a solution to deal with the above problems. Based on the black Box Testing Sistem after being tested, the sistem runs accordingly. Based on the results of the Mean Opinion Score (MOS), it shows that the average rating of respondents of website users is $73.32 \%$ and mobile users are worth $72.76 \%$.
\end{abstract}

Keywords: Taekwondo Sports, hybrid application, MOS.

*Penulis korespondensi

\section{Pendahuluan}

Taekwondo merupakan seni bela diri sekaligus sebagai olahraga nasional yang berasal dari Korea. Taekwondo berasal dari bahasa korea yang jika diterjemahkan menjadi "seni tangan dan kaki" atau "jalan" atau "cara kaki dan kepalan". Berdasarkan data yang didapat saat observasi dan wawancara, di Provinsi Nusa Tenggara Barat (NTB) tercatat ada 59 tempat latihan atau disebut juga Dojang. Dojang terbanyak ialah di Kota Mataram, yakni ada 12 dojang dengan Jumlah anggota sebanyak 360 anggota. Banyaknya anggota, mengakibatkan Pengurus Kota (pengkot) seringkali kewalahan dalam hal mengolah data anggota jika dilakukan secara manual. Selain itu, banyaknya kegiatan yang diikuti oleh anggota setiap tahunnya juga membuat pengkot harus mengumpulkan berkas yang sama untuk masing-masing kegiatan secara manual dan mengakibatkan penumpukan berkas. Selain itu berdasarkan observasi masalah yang juga sering terjadi yakni adanya manipulasi data saat Ujian Kenaikan Tingkat (UKT) yang membuat pengkot tidak mengetahui secara valid anggota yang ikut serta atau tidak ikut serta saat UKT. Oleh karena latar belakang tersebut, diharapkan dengan adanya aplikasi hybrid pengolahan data anggota dan Event ini maka akan mempermudah pengkot untuk mengelola data setiap anggota dan juga mengelola data peserta event-event yang di adakan pengkot Kota Mataram.

\section{STUDI LITERATURE}

Pada bagian ini akan dijelaskan studi literature berupa penelitian terkait yang sesuai dan juga dasar teori dari penelitian ini.

\subsection{Penelitian Terkait}

Terdapat beberapa penelitian tentang aplikasi yang digunakan pada cabang olahraga taekwondo yang berjudul "Alat Bantu Perwasitan pada Pertandingan Taekwondo". Penelitian ini bertujuan untuk memberikan nilai kepada atlet yang sedang bertanding. Scoring Machine disesuaikan dengan peraturan Taekwondo dari WTF (World Taekwondo Federation). Scoring Machine ini terdiri dari beberapa modul, yaitu modul masukan, modul mikrokontroler, dan program perwasitan untuk pertandingan taekwondo. Modul masukan berupa data dari tiga wasit sudut (judges), yaitu 12 buah push button. Mikrokontroler yang digunakan adalah Atmel AT89S51. Pemilihan mikrokontroller ini sudah sesuai dengan kebutuhan untuk scoring machine. Push button akan dihubungkan dengan mikrokontroler. Jika dua atau lebih wasit menekan tombol yang sama dalam jangka waktu 2 detik maka nilai akan keluar. Nilai yang didapatakan disimpan dan dapat dicetak sebagai laporan [2]. 
Selain yang telah dijelaskan diatas, terdapat juga pembuatan aplikasi QR code berbasis mobile telah dilakukan pada beberapa penelitian sebelumnya. Salah satunya yaitu berjudul "Implementasi Teknologi QRCode Untuk Kartu Identitas". Penelitian ini mengambil data dari dikti yang kemudian di konversi dalam bentuk gambar QR code. Dimana setelah data diperoleh maka akan dilakukan validasi untuk verifikasi data. Hasil QR code akan di-scan dengan masing-masing aplikasi yang dibuat [3]. Selain itu terdapat penelitian yag menggunakan QR code sebagai bahan untuk promosi dan media informasi dengan menggunakan smartphone yang memiliki sistem operasi android[4]

\subsection{Dasar Teori}

Pada penelitian ini digunakan sistem operasi android bagi perangkat bergerak yang dibuat karena android menyediakan platform terbuka bagi para developer untuk membuat aplikasi mereka. Terdapat beberapa faktor dan pertimbangan mengapa membuat aplikasi berbasis android, yaitu [5]:

1. Faktor Kecepatan dan tingkat efisiensi aplikasi dalam penyajian data, termasuk proses dalam memberikan output data secara cepat dan sesuai keinginan pengguna.

2. Aspek produktivitas, yaitu kebermanfaatan aplikasi guna meningkatkan produktivitas user.

3. Kreativitas desain dimana android menyediakan fleksibilitas pembuatan user interface sehingga pengembang dapat dengan mudah mendesain tampilan antarmuka yang mudah bagi pengguna.

Sementara itu pada proses pembuatan aplikasi ini menggunakan framework lonic, yaitu sebuah framework aplikasi mobile web berbasis HTML5 yang dapat digunakan untuk mengembangkan apikasi mobile dengan teknologi web seperti HTML, CSS, dan Javascript. Framework ionic memiliki kelebihan yaitu dapat dibuatnya aplikasi hybrid dengan multi platform yaitu antara lain untuk android, IOS, ataupun blackberry. Selain itu framework ionic juga open source dan mengadaptasi teknologi web terbaru. Ionic juga menggunakan Angular JS untuk implementasi logic-nya sehingga aplikasi yang dibuat akan dapat berjalan sangat cepat seperti halnya aplikasi native [6].

Hybrid application merupakan penggabungan dari HTML5 dan native yang artinya hybrid application akan dibuat menggunakan bahasa pemrograman web, namun akan berjalan seperti native application pada smartphone pengguna. Berikut pendekatan yang digunakan pada arsitektur aplikasi hybrid [7].

Sementara itu untuk evaluasi dari aplikasi ini menggunakan perhitungan MOS (Mean Opinion Score). perhitungan persentase rata-rata berasal dari setiap poin jawaban kuisioner, perhitungan yang digunakan adalah menggunakan rumus sebagai berikut:

Rata-rata $=($ Persentase ke- $1+. .+$ Persentase ke-5) $/ 6$

Persentase jawaban responden terhadap kuesioner yaitu, tidak setuju, kurang setuju, cukup, setuju dan sangat setuju dapat dihitung secara keseluruhan dan didefinisikan sebagai nilai rata-rata [8].

\section{Metode Usulan}

Pengembangan sistem pada penelitian ini dilakukan dengan menggunakan metode Waterfall, dimana metode Waterfall akan dilakukan dengan langkah-langkah yaitu analisa kebutuhan sistem dimana pada tahap ini akan dilakukan analisa terhadap sistem yang dibuat mulai dari cakupan sistem dan kelebihan sistem, langkah selanjutnya yaitu perancangan sistem menggunakan diagram UML, ERD untuk menggambarkan rancangan database, dan perancangan tampilan dari aplikasi yang dibuat. Langkah selanjuntya yaitu implementasi sistem yang menghasilkan aplikasi hybrid sesuai tujuan akhir penelitian ini, dan tahap terakhir yaitu pengujian sistem menggunakan black box dan MOS. Langkah pengembangan sistem dapat dilihat pada Gambar 1.

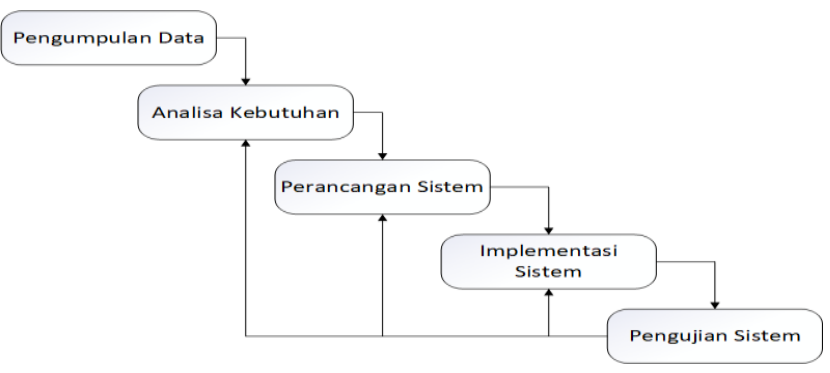

Gambar 1 Tahapan Model Waterfall

\subsection{Analisa kebutuhan}

Pada tahap ini dilakukan 4 proses analisa kebutuhan diantaranya analisis kebutuhan data atau materi, analisis kebutuhan fungsional, analisis perangkat lunak dan analisis perangkat keras. Pada analisis kebutuhan data digunakan beberapa metode pengumpulan data diantaranya wawancara dan observasi.

\subsubsection{Sistem yang ada Sekarang}

Saat ini Pengkot Mataram dalam mengelola data anggota taekwondo se- Kota Mataram masih dilakukan secara manual, seperti saat pendaftaran anggota baru yakni dengan cara mengisi formulir kemudian diserahkan Pelatih masing-masing, kemudian pelatih mendata ulang sebagai arsip dan diserahkan ke pengurus, sebagai laporan pelatih ke Pengkot. Pada saat UKT, Kejuaraan, atau Diklat Anggota atau Peserta mendaftarkan diri 
kepada pelatih dojang masing-masing. Anggota mengisi formulir dan membayar uang pendaftaran UKT kepada pelatih yang nantinya pelatih tersebut akan menyerahkan kembali ke Pengkot. Flowmap Sistem yang sekarang dapat dilihat pada Gambar 2.

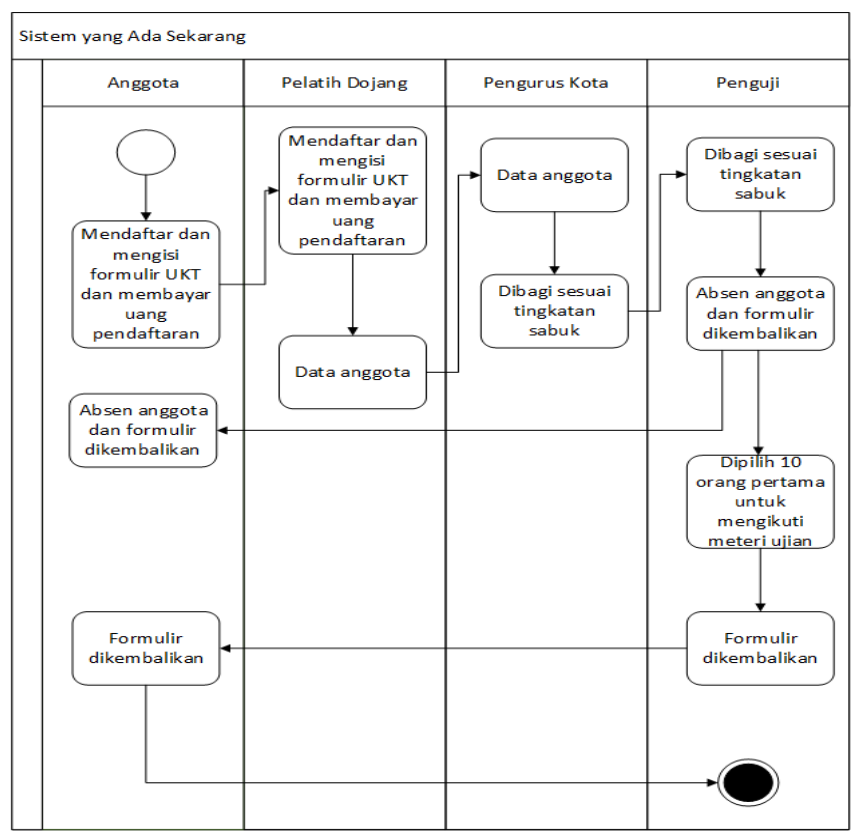

Gambar 2 Flowmap Sistem Yang Ada Sekarang

\subsubsection{Kebutuhan Sistem Yang Akan Dibuat}

Berdasarkan analisa kebutuhan yang dilakukan, berikut Flowmap Kebutuhan Sistem yang akan dibuat dapat dilihat pada gambar 3.

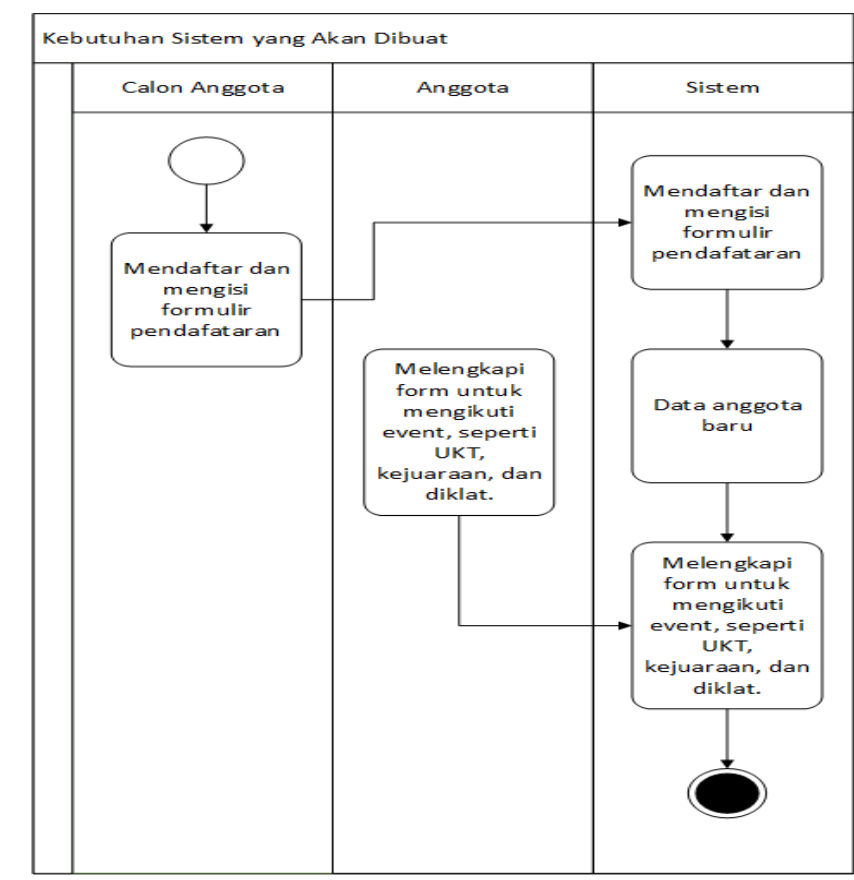

Gambar 3 Flowmap Sistem Usulan
Deskripsi kebutuhan sistem yang akan dibuat :

1. Data calon anggota baru, anggota yang mengikuti Event, seperti UKT, kejuaraan, dan diklat. Sehingga calon anggota maupun anggota mengisi formulir langsung di website taekwondo Kota Mataram.

2. Sistem yang akan dibuat ini memudahkan calon anggota baru mendaftarkan diri tanpa harus datang langsung ke tempat latihan, memudahkan anggota dalam mendapatkan informasi Event, seperti UKT, kejuaraan, dan diklat.

3. Informasi yang dapat dihasilkan dari sistem yang akan dibuat ini ialah data anggota taekwondo Kota Mataram, data pelatih Kota Mataram, dan Event yang diadakan maupun dilaksanakan oleh pengkot, seperti UKT, kejuaraan, dan diklat.

\subsection{Perancangan Sistem}

Proses perancangan sistem dapat dilakukan dengan merancang beberapa diagram yang dapat menggambarkan sistem yang akan dibuat, dalam hal ini dapat dilakukan dengan membuat use case diagram, class diagram, sequence diagram, activity diagram serta ERD dari sistem.

\subsubsection{Use case diagram}

Use case diagram menggambarkan proses yang dapat dilakukan masing- masing aktor, dimana pada sistem pengelolaan data anggota cabor taekwondo Kota Mataram pada sisi Website terdapat 3 aktor yaitu User (anggota) yang dapat melakukan proses mengisi Formulir Pendaftaran, melihat Anggota, melihat Event, mengisi formulir UKT, melihat pelatih, dan melihat pengurus. Aktor yang kedua yaitu Super Admin yang dapat mengelola pengurus Kota. Aktor yang Ketiga adalah Admin (Pengurus Kota) yang dapat melakukan Proses Rekapitulasi Data, Mengelola Event, dan Mengelola Pelatih.

Pada Sistem Pengolahan Data Anggota Cabor Taekwondo Kota Mataram dari sisi Mobile juga terdapat 3 Aktor yaitu User (anggota) yang dapat melakukan proses mengisi Formulir Pendaftaran, melihat Anggota, melihat Event, mengisi formulir UKT, melihat pelatih, dan melihat pengurus. Aktor yang kedua yaitu Super Admin yang dapat mengelola pengurus Kota. Aktor yang Ketiga adalah Admin (Pengurus Kota) yang dapat melakukan Proses Rekapitulasi Data dan Scan QR Code. Use case Diagram sistem Website dan Use case Diagram sytem Mobile yang akan dibuat bisa dilihat pada Gambar 4 dan 5 


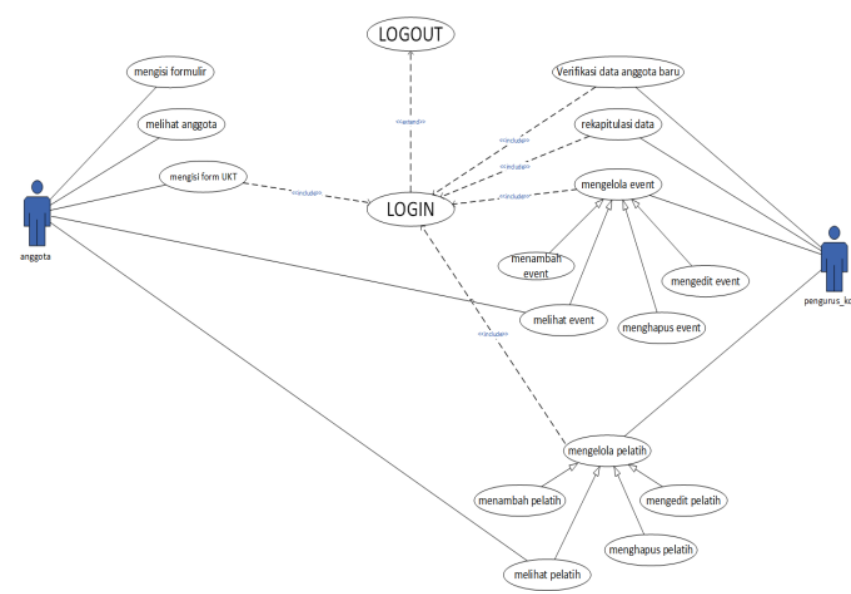

Gambar 4 Use case Diagram Website Pengolahan Data Anggota

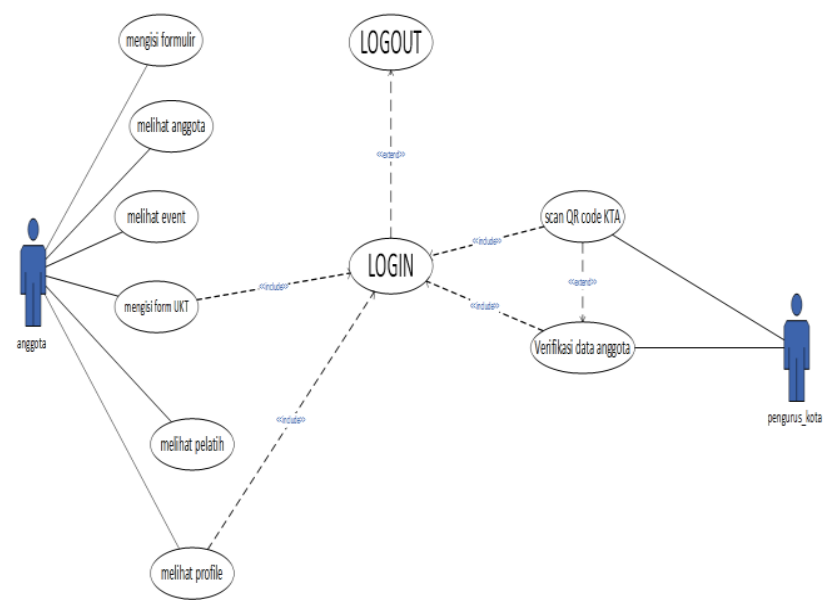

Gambar 5 Use case Diagram Mobile Pengolahan Data Anggota Cabor Taekwondo Kota Mataram

\subsubsection{Class diagram, sequence diagram, dan activity diagram}

Class diagram meggambarkan keadaan dari sistem pengelolaan data anggota cabor taekwondo Kota Mataram berupa atribut, method, serta hubungan masing-masing kelas, class diagram dari sistem pengelolaan data anggota cabor taekwondo Kota Mataram. Terdapat sebelas buah kelas yaitu kelas Cl_Controller, Cl_Model, Anggota, Event, Pelatih, Pengurus, User_Anggota, User_Event, User_Pengurus, User_Pelatih, Admin_Model, User_Model, Admin_View dan User_View.

Sequence Diagram menggambarkan tahapantahapan dari proses tertentu. Adapun Sequence diagram dari sistem pengelolaan data anggota cabor taekwondo Kota Mataram berjumlah sesuai dengan jumlah proses yang ada pada Use case Diagram.

Activity Diagram berfungsi untuk menggambarkan aktivitas massing-masing proses yang dilakukan oleh user dan alur dari masing-masing proses. Pembuatan activity diagram didasarkan pada Use case Diagram.

\subsubsection{ERD}

Diagram-ER memodelkan data yang ada dalam sistem pengelolaan data anggota cabor taekwondo Kota Mataram, dimana terdapat lima buah entitas yaitu Entitas pelatih dengan atribut id_pelatih, alamat, tempat_latihan, dan waktu_latihan, Entitas anggota dengan atribut id_anggota, dojang, nama, TTL, alamat, dan no_hp, Entitas Event dengan atribut id_Event dan nama_Event, Entitas admin dengan atribut id_admin, nama, dan alamat

Berikut Gambar Diagram ER Sistem Pengolahan Data Anggota Cabor Taekwondo Kota Mataram

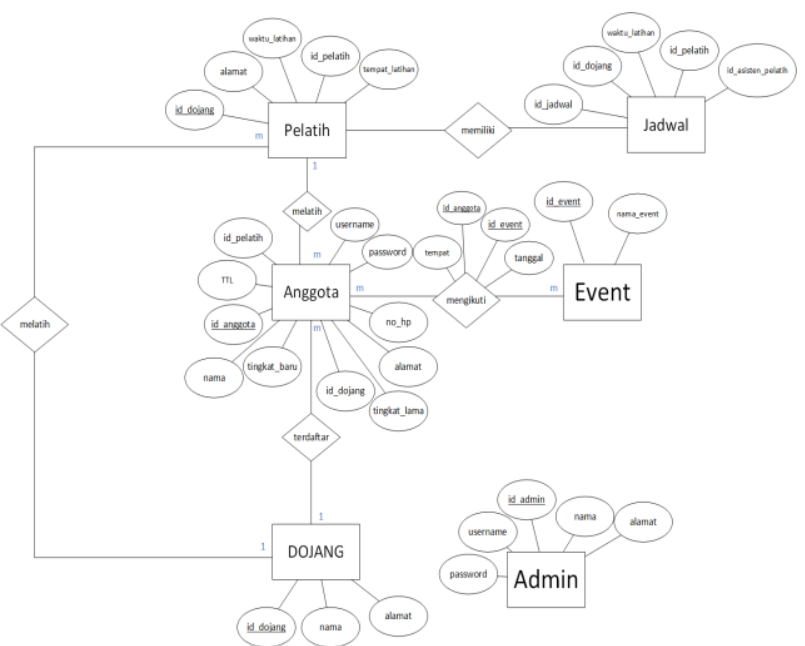

Gambar 6 ERD Sistem Pengolahan Data Anggota Cabor Taekwondo Kota Mataram

\subsubsection{Rancangan Tampilan Sistem}

Pada tahap ini akan di desain tampilan Website dan juga tampilan Aplikasi Mobile pada sistem pengelolaan data anggota cabor taekwondo Kota Mataram. Rancangan tampilan untuk user dan tampilan untuk super_admin dan pengurus_kota adalah sebagai berikut o Halaman Log in

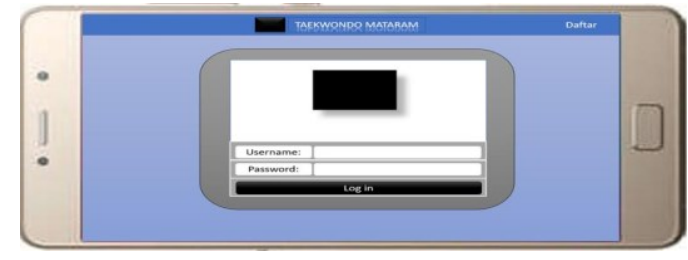

Gambar 7 Rancangan UI Halaman Log in 
- Halaman Daftar Nama Anggota

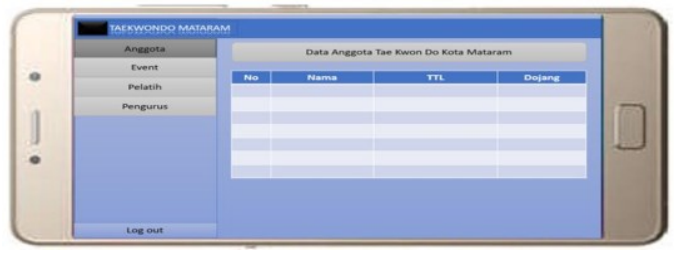

Gambar 8 Rancangan UI Halaman Daftar Nama anggota - Halaman Daftar Nama Event

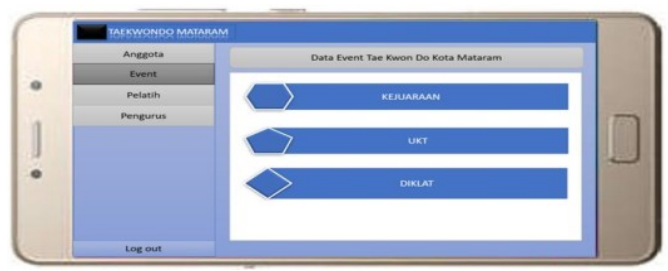

Gambar 9 Rancangan UI Halaman Event

- Halaman Pelatih

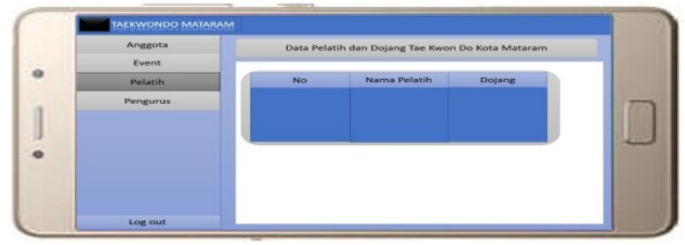

Gambar 10 Rancangan UI Halaman Pelatih

○ Halaman Pengurus

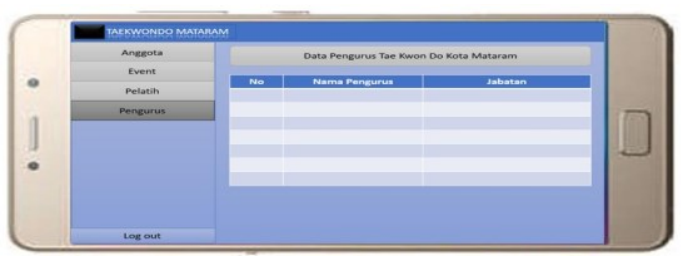

Gambar 11 Rancangan UI Halaman Pengurus

Rancangan tampilan untuk calon anggota atau user sebagai berikut

- Halaman Daftar

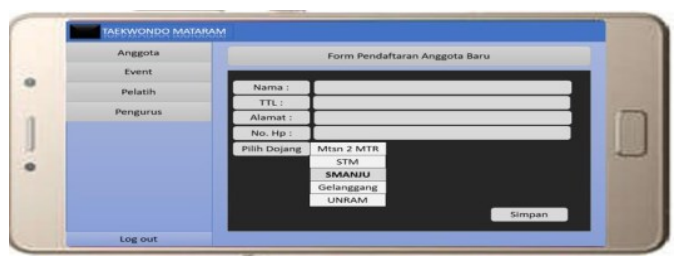

Gambar 12 Rancangan UI Halaman Daftar

- Halaman Scan dan hasil scan QR Code

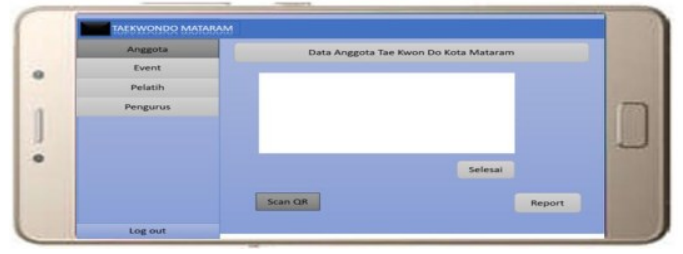

Gambar 13 Rancangan UI Halaman Scan QR Code

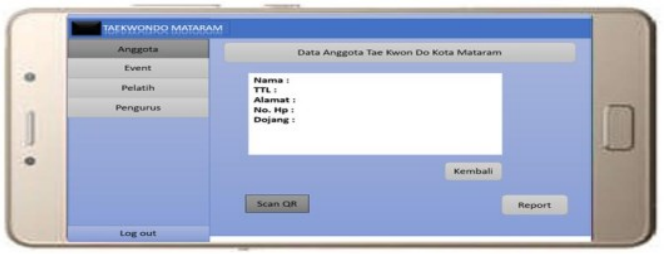

Gambar 14 Rancangan UI Halaman Hasil Scan QR Code

Rancangan tampilan untuk super_admin dan pengurus_kota yang diakses melalui Website sebagai berikut

○ Halaman Log In

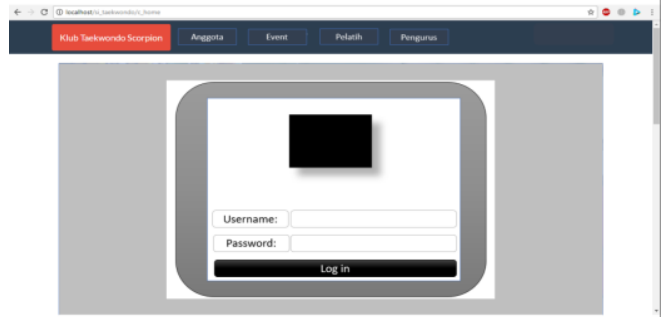

Gambar 16 Rancangan UI Website Halaman Login

- Halaman Anggota

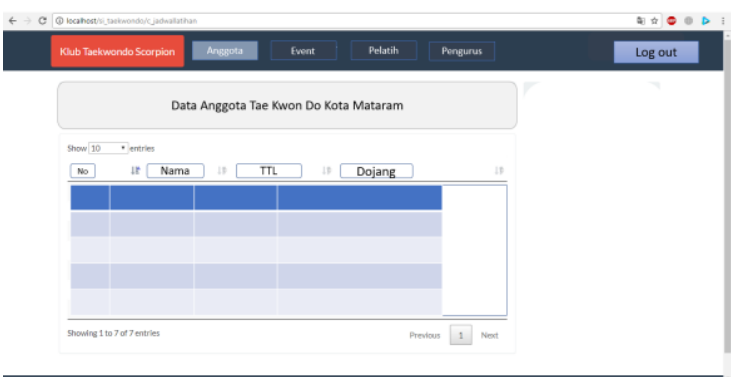

Gambar 17 Rancangan UI Website Halaman Anggota

○ Halaman Event

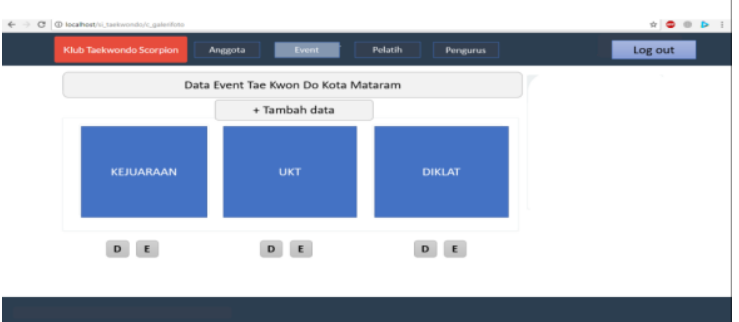

Gambar 18 Rancangan UI Website Halaman Event

- Halaman Pelatih

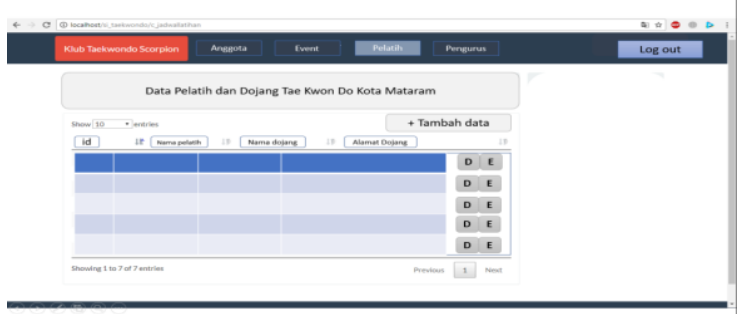

Gambar 19 Rancangan UI Website Halaman Pelatih 
- Halaman Pengurus

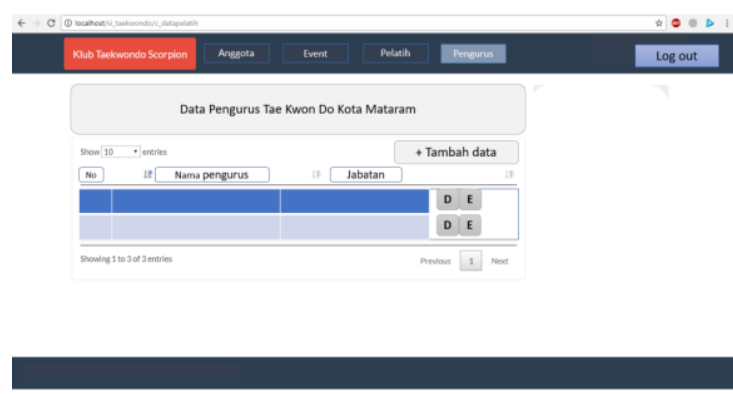

Gambar 20 Rancangan UI Website Halaman Pengurus

\subsection{Implementasi Sistem}

Implementasi sistem akan dilakukan dengan menggunakan framework Codelgiter untuk membuat website bagi user atau calon anggota maupun anggota. Serta membuat yang berbasis mobile untuk admin atau pengurus.

\subsection{Pengujian Sistem}

Pengujian, pada tahap ini akan dilakukan pengujian terhadap sistem yang telah dibuat dengan teknik Blackbox untuk mengetahui apakah semua fungsi perangkat lunak telah berjalan semestinya, Mean Opinion Score (MOS) untuk mengukur fungsional sistem dari aplikasi bergerak pengolahan data anggota dan QR Code.

Pada sistem pengelolaan data anggota cabor taekwondo Kota Mataram ini pengujian dilakukan dengan melihat fungsi sistem telah berjalan sesuai dengan fungsi yang didefinisikan yaitu sistem berhasil melakukan scan KTA, serta tidak ada lagi manipulasi data dan penumpukan berkas anggota.

Sementara kuisioner MOS yang dilakukan melibatkan Responden di dalam sistem yang dipersilahkan untuk mencoba dahulu aplikasi yang telah dibuat, dan kemudian memberikan penilaian subjektif dengan pilihan jawaban seperti pada Tabel I.

TABEL I NILAI MOS DAN TINGKAT KePUASANNYA[9]

\begin{tabular}{|c|c|}
\hline Nilai MOS & Tingkat Kepuasan \\
\hline 5 & Sangat baik \\
\hline 4 & Baik \\
\hline 3 & Cukup Baik \\
\hline 2 & Tidak Baik \\
\hline 1 & Buruk \\
\hline
\end{tabular}

Kuisioner dilakukan untuk mengetahui karakteristik dan performa dari sistem yang dibuat pada penelitian ini dan menjadi acuan untuk perbaikan sistem. Pada penelitian ini diberikan kuesioner kepada pengurus taekwondo kota mataram dan anggota ataupun calon anggota taekwondo.

\section{HASIL DAN PEMBAHASAN}

Pembahasan yang akan dijelaskan meliputi pembangunan database yang terintegrasi, pembangunan class sistem yang dibagi menjadi website dan mobile dan pembangunan interface yang dibagi menjadi Website dan Mobile. Selain itu, pada bagian ini juga akan dibahas mengenai hasil sistem yang telah dibuat, melakukan pengujian sistem serta mengevaluasi sistem yang telah berjalan.

\subsection{Implementasi Database}

Pada Sistem Pengelolaan Data Anggota Cabor Taekwondo Kota Mataram ini dibuat database dengan nama ta_taekwondo. Database yang dibuat dapat dilihat pada gambar 21 dimana pada database tersebut terdapat 7 tabel yang dapat digunakan secara bersamaan untuk aplikasi Website dan aplikasi Mobile.

\subsection{Implementasi Class Diagram}

Pembangunan class pada sistem pengelolaan data anggota cabor taekwondo kota mataram ini dibagi menjadi 2 bagian yaitu pembangunan kelas untuk aplikasi website bagi pengurus dan aplikasi mobile untuk anggota atau calon anggota.

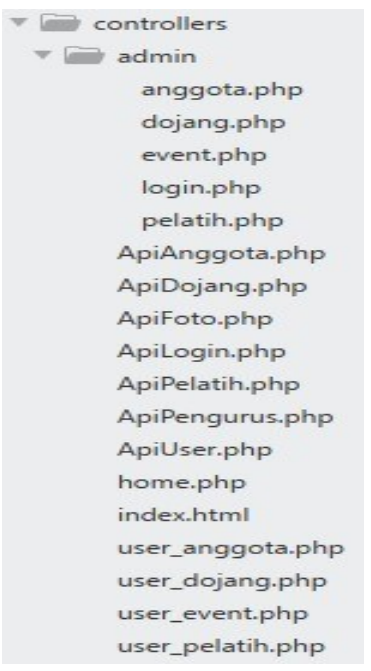

Gambar 22 Implementasi Class pada Controller

Implementasi Class pada View untuk Aplikasi Website dan Mobile. View merupakan kumpulan source code yang akan memberikăn tampilan didalam sistem dan akan berinteraksi dengan user. View akan menampilkan data-data yang berasal dari model yang telah diterjemahkan oleh controller.

Pada penelitian ini telah dibuat sebuah database yang terpusat dan digunakan secara bersama-sama bagi aplikasi bergerak juga aplikasi web yang dibuat. Database yang dibuat terdiri dari tujuh buah table yang saling terintegrasi dan digunakan bersama bagi seluruh fitur pada aplikasi hybrid pengolahan data anggota dan event pada cabang olahraga taekwondo di kota 
Mataram. Berikut merupakan database yang dibangun pada penelitian ini

Tabel * Tindakan
$\square$ admin Baris 9 Jenis

\section{Gambar 21 Database Sistem}

Implementasi Class pada Controller untuk Aplikasi Website dan Mobile. Data yang diperoleh dari query di model, akan ditampung ke dalam suatu variable oleh controller agar dapat ditampilkan ke view. Implementasi controller dalam pembuatan sistem ini terbagi menjadi dua bagian yaitu controller untuk website yang mengembalikan data PHP dan controller untuk aplikasi mobile yang mengembalikan data Json.

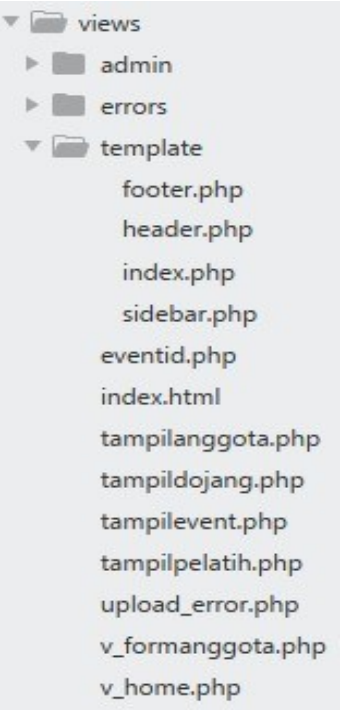

Gambar 23 Implementasi Class pada View Website

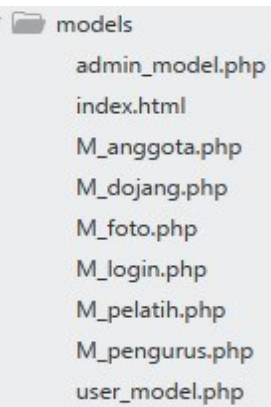

Gambar 24 Pembangunan Class pada model

Keseluruhan fungsi yang terdapat didalam model merupakan berbagai query yang digunakan oleh sistem untuk memanipulasi data yang dibutuhkan.

\subsection{Pembangunan Interface Sistem}

Interface merupakan antar muka yang memungkinkan pengguna dapat berinteraksi dengan sistem. Pada sistem ini Interface dibagi menjadi 2 yaitu Interface Website untuk pengurus dan Interface aplikasi Mobile untuk Anggota dan Pengurus.

\subsubsection{Interface di sisi Pengurus}

Interface Website disisi oleh admin adalah Interface halaman Login, halaman Data Dojang, halaman Tambah Dojang, halaman Edit Dojang, halaman Hapus Dojang, halaman Tambah Pelatih, dan halaman Tambah Event. Berikut beberapa Gambar Interface Website disisi oleh Admin.

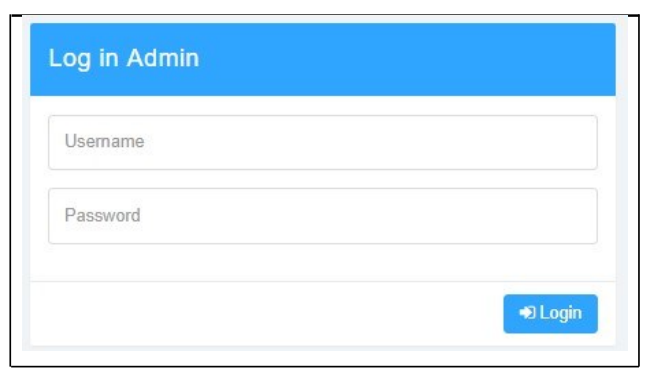

Gambar 25 Tampilan Halaman Login Pengurus

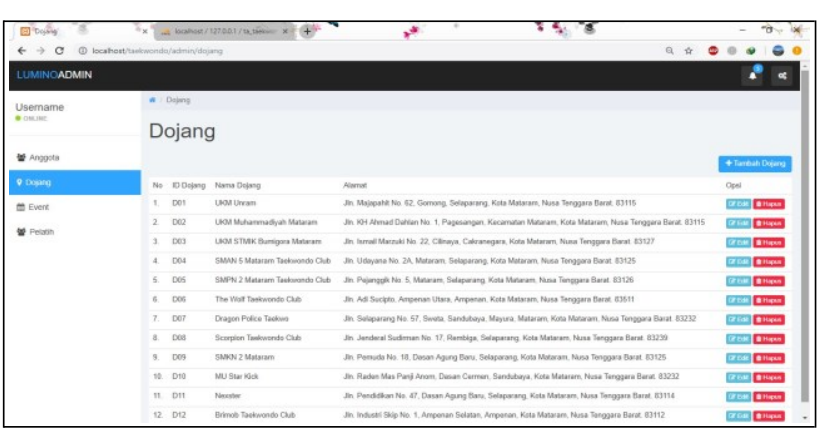

Gambar 26 Tampilan Halaman Data Dojang

\subsection{Interface Mobile diisi Anggota}

Interface aplikasi Mobile disisi anggota dan pengurus seperti Interface halaman Login, halaman Profil, halaman Anggota, halaman Event, halaman Pengurus, dan halaman Pelatih. Pada aplikasi Mobile ini fitur yang ada disisi pengurus sama dengan fitur yang ada disisi anggota. Berikut beberapa Gambar Interface Mobile disisi oleh Anggota

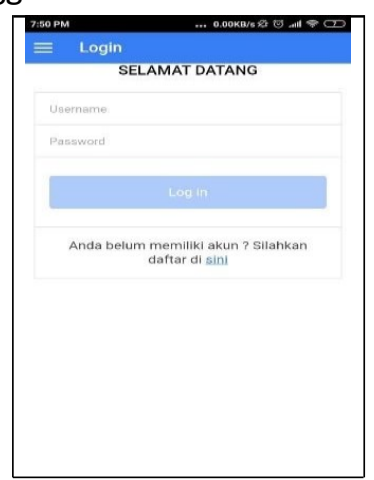

Gambar 27 Tampilan Halaman Login Mobile 


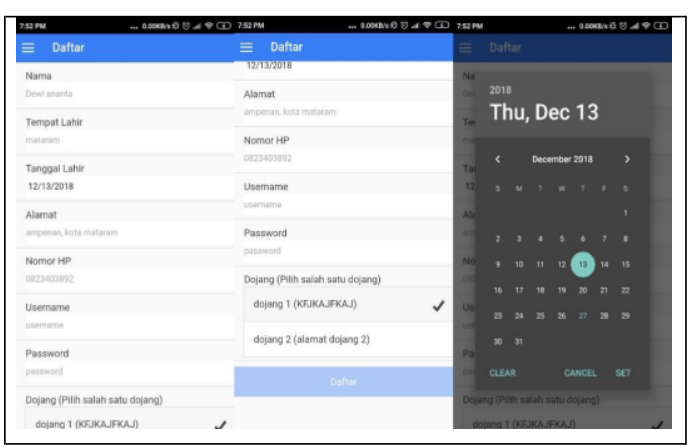

Gambar 28 Tampilan Halaman Daftar Mobile

Gambar 29 Tampilan Halaman Detail Anggota Mobile

\subsection{Pengujian Sistem}

Sistem yang telah menempuh tahap implementasi, akan memasuki tahapan pengujian sistem untuk mengetahui sejauh mana keberhasilan sistem dan kualitasnya. Pengujian sistem yang dilakukan antara lain dengan menggunakan metode pengujian Black Box dan juga metode pengujian kuesioner dengan MOS.

Metode pengujian Black Box merupakan metode pengujian yang memastikan fungsi-fungsi didalam sistem sudah berjalan sesuai denagn harapan atau tidak. Jika sesuai input dan output yang diharapkan maka dapat dikatakan fungsi atau fitur tersebut telah valid.

Tabel II Contoh Hasil Pengujian Blackbox Pada Login ADMIN

\begin{tabular}{|c|c|c|c|}
\hline Skenaris Renguijan. & $\begin{array}{l}\text { Hasil } \\
\text { Diharapkan }\end{array}$ & $\begin{array}{c}\text { Hasil } \\
\text { Penguian }\end{array}$ & Kesimpulan \\
\hline $\begin{array}{l}\text { Form username dan } \\
\text { password di isi dengan data } \\
\text { yang tidak sesuai }\end{array}$ & \begin{tabular}{l}
\multicolumn{1}{|c|}{ Proses login tidal } \\
berhasil dan alan \\
diroujuk kembali be \\
halaman login
\end{tabular} & Sesuai & Valid \\
\hline $\begin{array}{l}\text { Form username dan } \\
\text { password di isi dengan data } \\
\text { yang benar dan terdanat di } \\
\text { dalam database. }\end{array}$ & \begin{tabular}{|cr}
\multicolumn{1}{|c}{ Proses } & login \\
berhasil. admin & akan \\
memasulki sistem & dan \\
akan dirujuk & ke
\end{tabular} & Sesuai & Valid \\
\hline
\end{tabular}

Kuesioner disebarkan sembari menunjukkan sistem kepada responden untuk dijalankan. Setelah responden menjalankan sistem, kemudian diberikan kuesioner yang berisi 6 pertanyaan dengan 5 pilihan jawaban. Tujuan dari pengujian ini untuk mengetahui kualitas sistem yang dilihat dari sisi pengguna. Metode yang digunakan dalam pengujian kuesioner adalah metode kuantitatif, yaitu hasil pengujian ditentukan dalam suatu nilai angka.

Kuesioner pengujian sistem yang diberikan untuk pengguna website bagi pengurus, pelatih, dan asisten pelatih terdiri dari 6 pertanyaan, yaitu:

1. Apakah tampilan/desain sistem mudah dipahami?

2. Apakah sistem mudah digunakan?

3. Apakah sistem dapat membantu pengurus dalam mendapatkan informasitentang taekwondo kota Mataram?

4. Apakah sistem memudahkan pengurus dalam pengelolaan data sperti data anggota dan data

5. Apakah sistem berjalan dengan man baik?

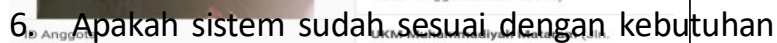

ANG2 taekwondo kota Mataram?

Kuésioner pengujian aplikasi yang diberikan untuk pengguna aplikasi mobile bagi anggota terdiri dari 6 pernyataan, yaitu:

1. Apakah tampilan/desain aplikasi mudah dipahami?

2. Apakah aplikasi mudah digunakan?

3. Apakah aplikasi membantu pengguna untuk mendaftar sebagai anggota?

4. Apakah aplikasi memudahkan anggota dalam mendapatkan informasi tentang taekwondo kota Mataram?

5. Apakah aplikasi berjalan dengan baik?

6. Apakah aplikasi sudah sesuai dengan kebutuhan taekwondo kota Mataram?

Apakah aplikasi sudah sesuai dengan kebutuhan taekwondo kota Mataram? Responden diminta untuk menjawab kuesioner tersebut dengan pilihan jawaban sebagai berikut :

$$
\begin{aligned}
& 1 \text { = Tidak Setuju } \\
& 2 \text { = Kurang Setuju } \\
& 3=\text { Cukup } \\
& 4=\text { Setuju } \\
& 5 \text { = Sangat Setuju }
\end{aligned}
$$

Berdasarkan jawaban tersebut, dilakukan perhitungan persentase dari setiap jawaban yang diberikan oleh penggunadisetiap pertanyaannya. Rumus untuk menghitung persentase jawaban adalah :

Persentase $=\mathrm{J} / \mathrm{N} * 100 \%$

Keterangan :

J : Total nilai jawaban yang diberikan pengguna pada setiap nomor.

$\mathrm{N}$ : Jumlah Pengguna

Selanjutnya dilakukan proses perhitungan persentase rata-rata dari setiap poin jawaban, perhitungan yang 
digunakan adalah menggunakan rumus sebagai berikut : Rata-rata $=($ Persentase ke- $1+\ldots . .+$ Persentase ke-5) $/ 6$

Hasil dari perhitungan jawaban responden terhadap pertanyaan yang diberikan untuk pengujian sistem Website dan Mobile dapat di lihat pada grafik gambar 30 dan 31.

Dari hasil pengujian kuesioner yang diperoleh, hasil dari perhitungan rata - rata seluruh pertanyaan, didapatkan nilai $0 \%$ untuk jawaban tidak setuju dan kurang setuju, sedangkan nilai untuk setuju, sangat setuju, dan cukup masing - masing bernilai 55,55\%, 17,77\%, dan 26.66\%. Representasi grafik dari hasil perhitungan nilai rata- rata jawaban responden, dapat dilihat pada Gambar 30.

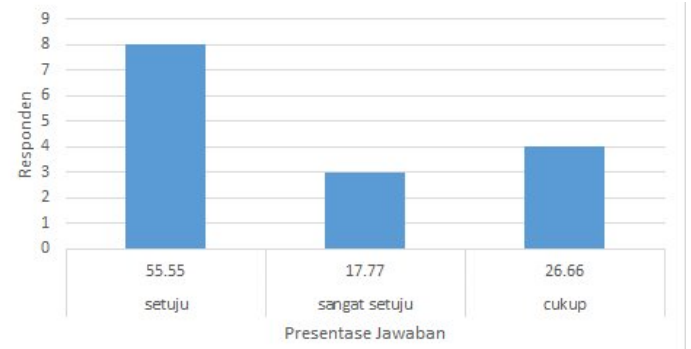

Gambar 30 Grafik persentase jawaban rata-rata responden pengguna website

Dari hasil pengujian kuesioner yang diperoleh, hasil dari perhitungan rata - rata seluruh pertanyaan, didapatkan nilai $0 \%$ untuk jawaban tidak setuju dan kurang setuju, sedangkan nilai untuk setuju, sangat setuju, dan cukup masing - masing bernilai 48,88\%, 17,77\%, dan $26,66 \%$. Representasi grafik dari hasil perhitungan nilai rata- rata jawaban responden, dapat dilihat pada Gambar 31.

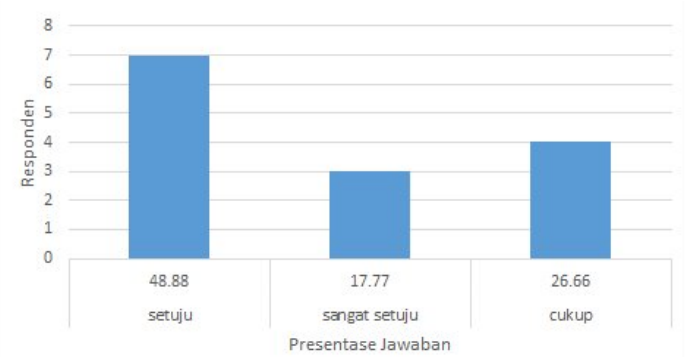

Gambar 31 Grafik persentase jawaban rata-rata responden pengguna mobile

Dari hasil pengujian kuesioner yang diperoleh, hasil dari perhitungan rata - rata seluruh pertanyaan, didapatkan nilai $0 \%$ untuk jawaban tidak setuju dan kurang setuju, sedangkan nilai untuk setuju, sangat setuju, dan cukup masing - masing bernilai 53,33\%, 21,12\%, dan $25,55 \%$. Representasi grafik dari hasil perhitungan nilai rata- rata jawaban responden, dapat dilihat pada Gambar 32.

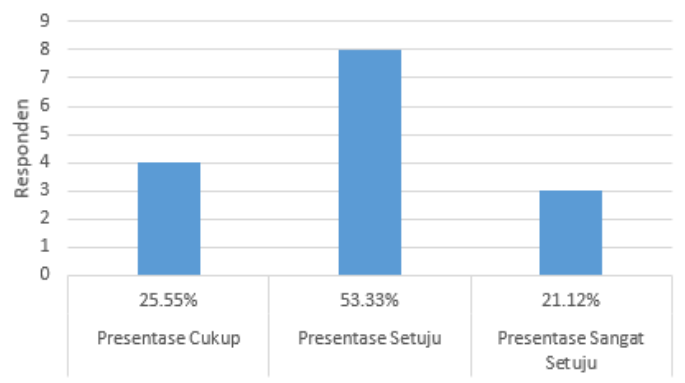

Gambar 32 Grafik persentase jawaban rata-rata responden pengguna mobile bagi anggota

\section{KESIMPULAN DAN SARAN}

Berdasarkan langkah-langkah dan hasil penelitian yang telah dilakukan, dapat ditarik beberapa kesimpulan dalam "Rancang Bangun Aplikasi Hybrid Pengolahan Data Anggota dan Event Pada Cabor Taekwondo Kota Mataram" diantaranya:

1. Pembuatan aplikasi hybrid dengan memanfaatkan web service pada tugas akhir ini dapat mengintegrasikan dua buah jenis aplikasi yang berbeda platform yaitu aplikasi pengolahan data anggota dan Event berbasis website untuk pengurus taekwondo Kota Mataram, dengan aplikasi mobile bagi anggota dan pengurus pada platform android.

2. Adanya sistem ini pengolahan data dan Event yang awalnya masih manual sekarang dapat dilakukan secara terkomputerisasi, dengan cara men-scan qr code anggota taekwondo kota Mataram untuk menghindari penumpukan berkas dan manipulasi data.

3. Menggunakan sistem ini calon anggota dan orang tua anggota dapat melihat jadwal latihan yang ada di Kota Mataram.

4. Hasil pengujian black box menunjukkan bahwa seluruh fungsi telah berjalan sesuai dengan sistem yang diusulkan.

5. Berdasarkan hasil Mean Opinion Score (MOS) menunjukkan bahwa rata-rata penilaian responden pengguna website bernilai $73,32 \%$ dan pengguna mobile bernilai $72,76 \%$.

Setelah proses penelitian ini dilakukan, ada beberapa saran yang akan peneliti sampaikan yaitu:

1. Untuk pengembangan selanjutnya diharapkan dapat membuat aplikasi yang dapat berjalan di sistem operasi mobile lainnya seperti iOS maupun windows phone.

2. Untuk penelitian selanjutnya, peneliti bisa menambahkan fitur push notifications agar pengguna aplikasi mobile dapat mengetahui notifikasi tanpa harus membuka aplikasi. 


\section{DAFTAR PUSTAKA}

[1] C. Liu, "Worldwide Internet and Mobile Users", eMarketer, Amerika Serikat, 2015.

[2] S.U Hadian, T. Harlianto, dan Y. Yanto, "Alat Bantu Perwasitan Pada Pertandingan Taekwondo", TESLA Vol. 10 No.1. Universitas Tarumanegara, Jakarta, 2008.

[3] A. Qashlim dan H. Hasruddin, "Implementasi Teknologi QR-Code Untuk Kartu Identitas". ISSN Vol. 1 No.2. Universitas Al Asyariah Mandar, 2015.

[4] A Wijaya dan A. Gunawan, "Penggunaan $Q R$ Code Sarana Penyampaian Promosi dan Informasi Kebun Binatang Berbasis Android", Jurnal Bianglala Informatika Vol. 4 No. 1 STMIK Nusa Mandiri, 2016.

[5] J.E. Istiyanto, "Pemrograman Smartphone Menggunakan SDK Android dan Hacking Android", Graha Ilmu, Yogyakarta, 2013.
[6] R. Abidin, Ionic Framework - Tool Untuk Membuat Aplikasi Mobile Lintas Platform, tersedia di https://teknojurnal.com diakses 05-05-2018.

[7] N. Mehta, Mobile Client Architecture Web vs Native vs Hybrid Apps, Tata Consultancy Service, Mumbai, 2012.

[8] K. Surya, Perhitungan MOS E-Model, tersedia di https://kdenotes.wordpress.com diakses 20-01-2019.

[9] S. Syaifullah, I. G. P. S. Wijaya, dan A. Y. Husodo, "Sistem Informasi Kepuasan Layanan Administrasi Akademik Berbasis IPA (Importance Performance Analysis) Studi Kasus Fakultas Teknik Universitas Mataram," J. Comput. Sci. Informatics Eng., vol. 2, no. 1, 2018. 